as in this case, the results are entirely at variance with those of profound and elaborate researches in the same direction which have preceled. We propose, therefore, to examine brielly only a very few points in the reasoning from which these results have becri dexluced.

The author states in the commencement that equilibrium is disturbed by the three following causes:---

(a.) Alteration of the specific gravity of the water or air.

(b.) The rotation of the earth on its axis.

(c.) The attraction of the sun and moon.

The accordingly treats the subject under these three gencral heads. Under the first two he endeavours to show that none of the usual causes to which the currents of the ocean and the atmosphere have been ustally referred can have much, if any, effect in modncing them, and that they must, therefore, be due to some other cause. This seems to be designed to make way for the introduction into this subject of the new disturbing forces contained above under the last head (c). Much might be said whit regard to what is stated under the frst two heads in dispararenent of the forces apon which thesc currents have been heretorore supposed to depend, but we shall confine ourselves here to a very few steps merely in the reasoning under the last head.

The anthor sets out under this head by assuming that the equilibrium theory of the tides is applicable to the real case of nature, and with this assmmption he endeavours to show that the food-tide rises higher above the plane of static equilbrium than the chb-tide sinks below it. Now, it is well known by all who are familar with tidal theories, that this theory is entirely worthlass as a representative of the ral tides of the ocean. ITere, then, there seems to be a weak place in the very foundation of the whole reasoning, and any results based upon it should be received with much distrust, if even all the following steps in the arrument were regarded as valid. In the second place, he attempts to show, hy a method which is very unscientific and incondusive, that the forcs of the sun and moon tend to produce a current from the east towards the west in the flood-tide, but the reverse of this in the ebh-tide. This is then followed by mother assumptiou in the following Ianguage:-- "Since, as we huve shown, the llood rises nore above the nomal level of the sea than the ebb sinks below if, we think we can assume, as an Jyprothesis, that the force of the lood-current will be grenter than that of the ebb-current." From this he infers that the difference in these forces must prodnce a constant current in the ocen in the toril zone from east to west, bat, for reasons which do not seen clear, the reverse of this toward the poles; and in this way, taking into account the defections of the continents, he accomts for all the ocean currents withont the ard of any of the usial canses assigned. In the case of the atmosphere he thinks that the same rasonmer must bold, bat atmits that in this che the atertion of the enecinc gravity by heat towad the equar moduce some additional and modifying effects. Siying nothing with regard to the steps in the argument, these revils are bascd npon a confessedy doubtitul hypohesis, and therefore should not be recival withont further proof

Plis is not a question to be settled by authority, but after tho frofond investigations of Laplace and Airy upon the tidal forces and the solvion of the tidal problem, from which no constant cumints around the emth were obtaned, we would sarcely cxpect that such results would be legitimately obtained in a few patres of verbal reasoning without the aid of mathematics. It is twa that more recently a very small effect of that lind has been obtained, tending to prodice a westward current in all latitudes, from which, by means of friction, the carth's rotation on its axis is supmed to be slighty changed, but this effect is of an onter almost infinitely small in comparison with those under consideration, and not at all contemplated in the anthor's reasoning, reverut to above.

Washington, D.C., Nox, 7,1874

\section{Mud Banks on Malabar Coast}

THF phenomenon of the " mud banks and of tracts of nud sus. penced in the sea" on certain parts of the Malabar coast, is not, as yon suppose (vol.xi. p. 35 ), unexplained. The late Capt. Mitchell, curator of the Madias Musenm, some years ago submitted a cuantity of the mud to microscopic examination, and published

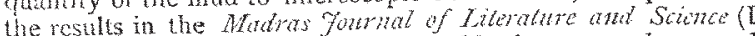
the results in the Matras format of 1 would give you volume and parcl. He found it to consist alnost entirely of Diatomacex, of which he defacted and distinguisher sixty-tyo species, In the paper in the Madras Joumal Capt. Mitchell gives a list of the genera and a numerical list of the specifo forms.

The causes, that have determined this local development of Diatomaces remain for investigation. They appear sometimes to shift their p'ace. Thus, a Dutch navirator (Stavounus, I believe) described two such banks as existing to the sonth of Cochin in 1777 , but these no longer exist.

Richmond, surey

HENEY T. BLANFOR

\section{Ring Blackbird}

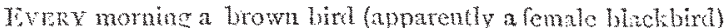
feeds at my library vindow. She lias a white spot on the breast, and a large white rinss, in the exact position of that on a Barbary dove, not meeting moer the chin. Is this on unusual variety? I see no mention of such a peculiarity in any of the books at hand, as Lewin, Bewick, Mudie, \&c. C. M. INGLEmy

Valentines, Ifrord, fan. 4

\section{ON THE MORPHOLOGY OF CRYSTALS*}

DROFESSOR MASKELYNE, in introducing his subject, said that in the assembly room of the Chemical Socicty he should have to treat of Crystallography as the Science of Chemical Morphology. To the chemist the crystallisation of a substance is a familiar marvel; so familar, indeed, that he hardly sufficiently considers its importance in relation to his own science. For the physicist, on the other hand, the instinct with which the molecules of a substance obey the laws of a sublime geometry-sublime because simple and universal-is $\mathrm{a}$ theme the contemplation of which has guided him to some of the most subtle and almost metaphysical conceptions that he has formed regarding the constitution of matter, and has afforded him invaluable insirht into the working of the laws that control the pulsations of heat and light and other manifestations of force. But, although the norpholosical relations of the crystal are the external expression of the more subtle physical properties which underlic them, he stated that the pumpose of the rectures he was about to delver woukl be confmed to the considention ontly of the former.

Placing a large and very perfect crystal of apophyllite from the Cluits of India on the table, the lecturer pointed out that certain faces carrying peculiar striations were reperted four times; that again othe:s of a tringulat form, planted on the anyles of the latter, were repented eight times, and that these had a lustre of thet own ; whle arain a plane of octagonal form was repcated oniy once on the top and at the bottom of the crystal, and carred a peculiar roughened surface, which was seen to be mado up of innumerable small square pyrtmicts in parallel positions. He further showed that by tuning the crystal round about an axis perpendicular to the last planes, the relative siuations of the plancs, as riawed from any point, cane always to be the same at any revolution through a quater of a circle. A group of fices repeated with similat propertics was defined as a $f * m$, the crystal in question thus cxhibiting three foms ; the repeated faces of each form retainin: the same general aspect so long as they were not moved round through an angle greater or less than $90^{\circ}$. When taking crystals of quartz which presented the same forms, he pointed out that faces that corresponded to one another on the different crystals, and even on the same crystal, have very different relative magnitudes; and that, in fact, these magnitudes were controlled by no rigid seometrical law. On the other hand, the angles which measured the inclination of corresponding faces on each other were in every case identical; hence angular inclination, that is to say, the direction in space, not relative position, that is to say, precise mutual distance, in the faces, has to be rccognised as a principle

* Some noter of the lectures delivered at the Clemical Society"s rooms in Burlington Housc, on the Morphology of Crystids, by Por N. $S$. Maskelyne, F.R.S. 